Original article

\title{
The demersal fish assemblage of the coastal area adjacent to the Tagus estuary (Portugal): relationships with environmental conditions
}

\section{L'assemblage des poissons des zones côtières adjacents à l'estuaire du Tage (Portugal) : relations avec l'environnement}

\author{
Nuno Prista ${ }^{\mathrm{a}, *}$, Rita Pina Vasconcelos ${ }^{\mathrm{a}}$, Maria José Costa ${ }^{\mathrm{a}, \mathrm{b}}$, Henrique Cabral ${ }^{\mathrm{a}, \mathrm{b}}$ \\ ${ }^{a}$ Instituto de Oceanografia, Faculdade de Ciências da Universidade de Lisboa, Campo Grande, 1749-016 Lisboa, Portugal \\ ${ }^{b}$ Departamento de Biologia Animal, Faculdade de Ciências da Universidade de Lisboa, R. Ernesto de Vasconcelos Bloco C-2, 3 piso, Campo Grande, \\ 1749-016 Lisboa, Portugal
}

Received 18 November 2002; received in revised form 8 March 2003; accepted 24 March 2003

\begin{abstract}
The subtidal fish assemblage of Tagus estuary coastal area was sampled in order to infer about its relationship to environmental conditions and its possible nursery function for marine species. Fish sampling took place between May 2001 and February 2002 with an otter trawl. In addition to fish sampling, a physical, chemical and biological characterization of the water column and bottom sediment was performed. Density and biomass were determined and ecological and feeding guilds assigned to each fish species. Correspondence analysis (CA) was used to determine the spatio-temporal structure of the assemblage and its correlation to environmental variables. A total of 36 fish species were identified. The fish assemblage was dominated by few species, both in terms of density and biomass. The main fish species were Callionymus lyra, Arnoglossus laterna, Diplodus bellotti, Echiichthys vipera and Raja undulata. Seasonally Trachurus trachurus, Sardina pilchardus and Engraulis encrasicolus were also abundant. Over 50\% of the fish caught were juvenile stages. Benthic carnivorous species feeding on invertebrates dominated the assemblage. CA results indicated that distinct fish species occur in the northern and southern areas, although they distance only a few kilometres from each other. Depth and sediment type were the main structuring factors of the fish assemblage. Temperature and salinity showed reduced importance on overall assemblage structure although that may result from the particular climatic regime of the sampling year. The environmental preferences of the most important species are briefly discussed and the importance of integrating various spatial scales in multispecific studies of coastal fish assemblages emphasized. The presence of high densities of marine species juveniles indicates that this area may function as a spring-summer nursery for several species.
\end{abstract}

() 2003 Éditions scientifiques et médicales Elsevier SAS and Ifremer/CNRS/IRD. All rights reserved.

\section{Résumé}

L'assemblage des poissons de la zone côtière adjacente à l'estuaire du Tage a été prospecté avec un chalut entre mai 2001 et février 2002. En plus de la récolte des poissons, les caractéristiques physiques, chimiques et biologiques du fond et de la colonne d'eau ont été suivies. La densité, la biomasse, l'abondance des juvéniles, les guildes trophiques et écologiques ont été déterminées. L'analyse de correspondance a été utilisée pour analyser la structure spatio-temporelle de l'assemblage des poissons. On a identifié 36 espèces de poissons. L'ensemble est dominé par très peu d'espèces en densité et en biomasse. Les espèces principales sont Callionymus lyra, Arnoglossus laterna, Diplodus bellotti, Echiichthys vipera et Raja undulata. A certaines périodes de l'année, Trachurus trachurus, Sardina pilchardus et Engraulis encrasicolus étaient aussi abondantes. Plus de $50 \%$ des individus étaient des juvéniles. Les espèces carnivores qui se nourrissent d'invertébrés dominent l'assemblage. Les résultats de l'analyse de correspondance indiquent que différentes espèces de poissons occurrent dans les zones Nord et Sud bien qu'elles soient très proches. La profondeur et le type de sédiment sont les facteurs structurants de la communauté des poissons. La température et la salinité montrent une importance réduite dans toute la structure de la communauté, bien qu'elles puissent résulter du régime climatique particulier de l'année des captures. Les préférences environnementales des espèces les plus importantes sont discutées ainsi que l'importance d'intégrer les plusieurs échelles spatiales dans les études multispécifiques des communautés de poissons

* Corresponding author. Fax: +351-21-750-00-09.

E-mail address: nuno.prista@fc.ul.pt (N. Prista). 
côtiers. La présence de grandes densités de juvéniles des poissons marins montrent que cette zone peut fonctionner comme une nurserie au printemps été pour plusieurs espèces de poissons.

(c) 2003 Éditions scientifiques et médicales Elsevier SAS and Ifremer/CNRS/IRD. All rights reserved.

Keywords: Coastal area; Fish assemblage; Community structure; Environmental conditions; Tagus estuary

Mots clés : Zone côtière ; Assemblage de poissons ; Structure de la communauté ; Environnement ; Estuaire du Tage

\section{Introduction}

Estuaries are far more productive ecosystems than the open sea (Day et al., 1981) and their importance for fish and fisheries has long been recognized all over the world (Blaber et al., 1989; Elliott and Dewailly, 1995). This importance is related to the fact that estuarine fish communities are seasonally dominated by high densities of juvenile stages of marine species (Day et al., 1981). Despite their recognized importance as nursery areas, some controversy exists as to whether or not marine fish species are really dependent on estuaries or just opportunistically using them in order to achieve higher growth rates and a lower exposure to piscivorous predation than found in other inshore coastal areas (Lenanton and Potter, 1987). An increasing body of evidence has been gathered showing that shallow inshore coastal areas may also act as nursery grounds (Lenanton, 1982; Ross et al., 1987; Wright, 1988; Blaber et al., 1995) and can have fish assemblages that include not only species common to both adjacent estuarine and offshore areas, but also characteristic species of their own, not present in nearby marine/estuarine habitats (Blaber et al., 1995). Although recognizing the importance of shallow coastal areas for juvenile fish, recent studies on European coastal waters have frequently used single species approaches and/or neglected less commercially important species (Safran, 1990). As a consequence the contribution of many coastal marine species, some of which important bycatch of fisheries, to shallow water soft-bottom coastal fish assemblages is largely unknown. This is particularly the case of Southern Europe, where few reports include a multispecific approach to fish assemblage (Safran, 1990; Cabral et al., 2000; Letourneur et al., 2001).

Concomitantly, most of the research concerning the relationships between environmental conditions and fish distribution in coastal grounds has been focused on estuaries. Several factors have been reported to influence fish species distribution amongst which depth, salinity, temperature, oxygen concentration, turbidity, sediment characteristics, habitat variability and productivity (Cabral, 2000; Thiel et al., 1995; Marshall and Elliott, 1998; Whitfield, 1999). The fish assemblage of Tagus estuary has been studied last decades and several fish species have been reported to make extensive use of the estuary both in a permanent, seasonal or occasional way (Costa and Bruxelas, 1989; Costa and Cabral, 1999). The available literature on the fish communities of Tagus coastal area suggests that the area is probably important as nursery ground for some marine species which have been reported in decreasing abundances inside the estuary (Cabral et al., 2000). Although this latter study included an extensive sampling programme, with both seasonal and diel coverage through beach seining, it was spatially restricted to an intertidal area located a few kilometres south of Tagus mouth and did not address possible relationships between species abundance and the environmental conditions of the area. The aim of the present work is to analyse the spatial and temporal structure of the fish assemblage of the coastal area adjacent to the Tagus estuary and to evaluate the relative contribution of several environmental variables to the distribution patterns of its main fish species.

\section{Materials and methods}

\subsection{Study area}

The Tagus estuary has an area of approximately $320 \mathrm{~km}^{2}$ of which $40 \%$ is intertidal. The Tagus river flow regime presents significant interannual and seasonal variations and is highly dependent on the climatic events occurring in the central part of the Iberian Peninsula (Gaudêncio et al., 1991) and on the outflow rates of several Portuguese and Spanish dams. An annual average flow of $400 \mathrm{~m}^{3} \mathrm{~s}^{-1}$ is generally reported with monthly averages fluctuating between 100 and $2200 \mathrm{~m}^{3} \mathrm{~s}^{-1}$ (Cabeçadas et al., 2000). The Tagus river outflows from the estuary through a narrow channel $12 \mathrm{~km}$ long, $2 \mathrm{~km}$ wide and about $30 \mathrm{~m}$ deep. Near Cape São Julião and the Bugio island, it opens into a large bay limited on its northern boundary by a mixture of rocky shores and sandy beaches and on its southern boundary by sandy beaches. The bay has two main navigation channels: a deeper canyon in the NE-SW direction and a secondary shallower navigation channel along the northern coastline (Fig. 1). Sediments are essentially sandy with coarser sands occurring in the northern sector whilst offshore mud deposits occur in the outer shelf below 80 m (Dias, 1987; Jouanneau et al., 1998). Tidal regime is primarily semidiurnal with a range of $1.5 \mathrm{~m}$ in neap tides and of $3.5 \mathrm{~m}$ in spring tides. The tidal currents are highly dependent on the bathymetry of the area with surface currents more intense over the shallower areas than in the main canyon during the flood and an opposite situation during the ebb. The bathymetry and coast morphology also contribute to a situation of tidal reversion near the coast during the ebb due to eddy formation on both sides of the larger canyon (Fortunato et al., 1997). Upwelling favourable winds from northern octants occur in summer (Fiúza et al., 


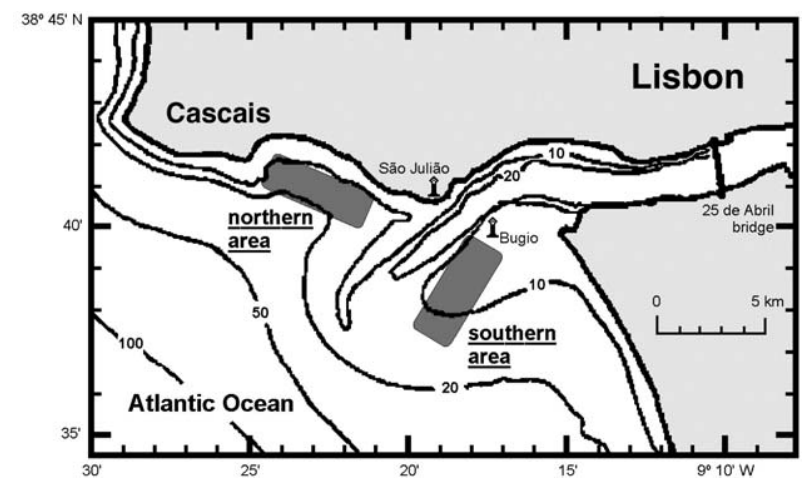

Fig. 1. Location of the sampling sites in the coastal area adjacent to the Tagus estuary with reference to northern and southern trawled areas.

1982) and strong SW winds are common in winter months. The area is relatively protected from the dominant NW swell of the Portuguese coast, although it is exposed to seasonal SW storms (Dias, 1987).

\subsection{Sampling techniques}

Three samples were taken from each of two areas-located north and south of the main channel of the Tagus estuary_in May 2001, September 2001, November 2001 and February 2002 (Fig. 1). Fish samples were taken with an otter trawl (14.2 m headline, $21.5 \mathrm{~m}$ footrope, $50 \mathrm{~mm}$ body stretched mesh, $18 \mathrm{~mm}$ cod-end stretched mesh). All tows lasted $15 \mathrm{~min}$ and were carried out in daylight and in neap tide, at a constant speed of 2.5 knots. Immediately before and after each tow, depth, temperature, salinity and dissolved oxygen concentration were measured with an YSI 600 XLM probe near the bottom ( $0.5 \mathrm{~m}$ over the bottom) and the surface $(0.5 \mathrm{~m}$ depth). Also before the tow, water transparency was measured with a Secchi disc and 101 of bottom and surface water were collected with a Wilco horizontal alpha bottle for chlorophyll and suspended solids' determination. Furthermore, a sediment sample was obtained with a van Veen grab and immediately frozen for determination of organic content and grain size composition of sediment.

\subsection{Laboratory procedures}

All fish were identified, measured (total length with $1 \mathrm{~mm}$ precision) and weighed (wet weight with $0.01 \mathrm{~g}$ precision). Three water subsamples were filtered (Whatman GF/F filters) for both chlorophyll $a$ and total and volatile suspended solids quantification. Chlorophyll extraction was performed in $90 \%$ aqueous acetone solution and chlorophyll $a$ quantified according to the Lorenzen (1967) spectrophotometric method. Total suspended solids were quantified after oven drying of filters for $24 \mathrm{~h}$ at $60{ }^{\circ} \mathrm{C}$. Volatile suspended solids were determined after ignition of filters at $550^{\circ} \mathrm{C}$ for $2 \mathrm{~h}$. The Clesceri et al. (1998) formulas were used to quantify total and volatile suspended solids.

Sediment samples were dried at $60{ }^{\circ} \mathrm{C}$ and a $100 \mathrm{~g}$ subsample wet-sieved through a $0.063 \mathrm{~mm}$ mesh sieve and dried.
The remaining sediment was sieved through a four-sieve column. The weight of the residue remaining in each sieve was then expressed as a percentage of the total subsample weight and the $<0.063 \mathrm{~mm}$ fraction calculated from the difference between the initial subsample weight and the sum of the other fractions. The following categories of grain size were considered: mud $(<0.063 \mathrm{~mm})$, fine sand $(0.063-0.125$ $\mathrm{mm})$, medium sand $(0.125-0.500 \mathrm{~mm})$, coarse sand $(0.500-2$ $\mathrm{mm}$ ) and gravel (>2 mm). Organic content of sediment was quantified by the loss on ignition method at $550{ }^{\circ} \mathrm{C}$ during 4 $\mathrm{h}$ (Heiri et al., 2001) of three $5 \mathrm{~g}$ oven dried sediment subsamples.

\subsection{Data analysis}

In order to evaluate the main spatial and temporal variations in both environmental variables and fish assemblage characteristics (species richness, fish density and biomass), two-factor Model I analyses of variance (ANOVAs) were conducted. Species densities and biomass were defined as the number of individuals per hour (ind. $\mathrm{h}^{-1}$ ) and as grams of wet weight per hour $\left(\mathrm{g} \mathrm{h}^{-1}\right)$, respectively. The proportion of juveniles assigned to each species was based on the size at first maturity reported in literature (see Appendix A), but as the juvenile density of some species may have been underestimated due to mesh size selection, the ANOVA was not performed on this parameter. The factors used in ANOVA were area (North, South) and sampling date (May, September, November, February). A significance level of 0.05 was considered. If the null hypotheses were rejected a posteriori multiple comparisons were performed using the Tukey honestly significant difference tests (Zar, 1999). Whenever the raw data did not fulfil the ANOVA assumptions of normality and homocedasticity, the data was transformed (Zar, 1999). To compare the fish assemblage functional structure with the one found in the adjacent estuary, the species were classified into two types of guilds: (a) an ecological guild adapted from Lenanton and Potter (1987) that comprehends estuarine resident species (ER), marine species which are predominantly found in estuaries at some stage of their life cycle (ME), species which are frequent in both estuarine and coastal inshore areas (MEI), diadromous migrant species (D) and freshwater species $(\mathrm{FW})$, based on what is known for the Portuguese coast and Tagus estuary; (b) a feeding guild adapted from Elliott and Dewailly (1995) based on studies conducted in the Portuguese coast and in the Tagus area (including unpublished data on stomach contents of the most abundant species in the study area). The food categories used were planktivorous $(\mathrm{P})$, invertebrate feeders $(\mathrm{I})$, piscivorous (F), omnivorous $(\mathrm{O})$ and detritivorous (D).

Correspondence analysis (CA) was used to identify the underlying structure of the fish assemblage and possible relationships of that structure to environmental variables. The CA is an ordination method effective for indirectly 
Table 1

Environmental parameters values in Tagus coastal area per area and sampling date. Means and standard deviations of bottom (bot.) and surface (surf.) measurements are presented. CA code refers to the codes used in correspondence analysis diagram

\begin{tabular}{|c|c|c|c|c|c|c|c|c|c|}
\hline \multirow[t]{2}{*}{ Environmental variable } & \multirow[t]{2}{*}{ CA code } & \multicolumn{3}{|c|}{ Area } & \multicolumn{5}{|c|}{ Sampling date } \\
\hline & & $n$ & South & North & $n$ & May & September & November & February \\
\hline \multicolumn{10}{|l|}{ Sediment } \\
\hline $\operatorname{Mud}(\%)$ & mud & 11 & $1.2 \pm 0.7$ & $4.4 \pm 2.0$ & $6^{\mathrm{a}}$ & $2.1 \pm 1.1$ & $3.4 \pm 2.7$ & $3.7 \pm 2.5$ & $2.3 \pm 2.6$ \\
\hline Fine sand $(\%)$ & $f_{s}$ & 11 & $45.7 \pm 20.3$ & $83.8 \pm 12.6$ & $6^{\mathrm{a}}$ & $68.0 \pm 24.6$ & $75.5 \pm 23.0$ & $60.4 \pm 30.6$ & $58.7 \pm 26.6$ \\
\hline Medium sand (\%) & $m s$ & 11 & $50.2 \pm 19.4$ & $8.8 \pm 12.9$ & $6^{\mathrm{a}}$ & $27.1 \pm 26.3$ & $19.1 \pm 25.5$ & $31.8 \pm 30.7$ & $36.4 \pm 28.2$ \\
\hline Coarse sand $(\%)$ & $c s$ & 11 & $2.7 \pm 2.2$ & $2.4 \pm 0.9$ & $6^{\mathrm{a}}$ & $2.0 \pm 0.7$ & $1.7 \pm 0.5$ & $3.7 \pm 2.8$ & $2.5 \pm 1.1$ \\
\hline Gravel (\%) & grv & 11 & $0.1 \pm 0.1$ & $0.7 \pm 0.7$ & $6^{\mathrm{a}}$ & $0.8 \pm 0.9$ & $0.3 \pm 0.2$ & $0.5 \pm 0.5$ & $0.1 \pm 0.1$ \\
\hline Organic content $(\%)$ & - & 11 & $0.9 \pm 0.2$ & $1.9 \pm 0.3$ & $6^{\mathrm{a}}$ & $1.4 \pm 0.5$ & $1.5 \pm 0.6$ & $1.5 \pm 0.6$ & $1.3 \pm 0.6$ \\
\hline \multicolumn{10}{|l|}{ Water column } \\
\hline Depth (m) & dpth & 24 & $10.56 \pm 2.29$ & $17.60 \pm 1.18$ & 12 & $14.18 \pm 4.30$ & $13.71 \pm 3.76$ & $14.28 \pm 4.32$ & $14.13 \pm 4.05$ \\
\hline Temperature surf. $\left({ }^{\circ} \mathrm{C}\right)$ & $S t$ & 24 & $17.16 \pm 1.31$ & $17.09 \pm 1.06$ & 12 & $16.98 \pm 0.36$ & $18.31 \pm 0.36$ & $17.86 \pm 0.09$ & $15.34 \pm 0.25$ \\
\hline Temperature bot. $\left({ }^{\circ} \mathrm{C}\right)$ & Bt & 24 & $16.36 \pm 1.19$ & $15.97 \pm 1.19$ & 12 & $14.84 \pm 0.37$ & $16.54 \pm 0.51$ & $17.84 \pm 0.11$ & $15.44 \pm 0.14$ \\
\hline Salinity surf. & Ss & 24 & $34.59 \pm 0.69$ & $34.50 \pm 1.16$ & 12 & $34.11 \pm 0.94$ & $34.28 \pm 0.29$ & $33.94 \pm 0.42$ & $35.86 \pm 0.35$ \\
\hline Water transparency $(\mathrm{cm})$ & $w t$ & $12^{\mathrm{b}}$ & $389 \pm 82$ & $491 \pm 113$ & $6^{\mathrm{b}}$ & $473 \pm 72$ & $343 \pm 45$ & $370 \pm 73$ & $525 \pm 118$ \\
\hline Oxygen surf. $\left(\mathrm{mg} \mathrm{m}^{-3}\right)$ & So & 18 & $8.62 \pm 0.69$ & $8.71 \pm 0.69$ & 6 & $9.44 \pm 0.21$ & - & $7.85 \pm 0.17$ & $8.70 \pm 0.13$ \\
\hline Oxygen bot. $\left(\mathrm{g} \mathrm{m}^{-3}\right)$ & Bo & 18 & $8.46 \pm 0.67$ & $7.96 \pm 0.46$ & 6 & $8.73 \pm 0.55$ & - & $7.52 \pm 0.19$ & $8.37 \pm 0.21$ \\
\hline Total susp. solids surf. $\left(\mathrm{g} \mathrm{m}^{-3}\right)$ & $t s$ & 12 & $21.8 \pm 7.0$ & $22.0 \pm 6.1$ & 6 & $11.7 \pm 1.9$ & $25.0 \pm 2.6$ & $26.9 \pm 2.0$ & $24.0 \pm 1.3$ \\
\hline Total susp. solids bot. $\left(\mathrm{mg} \mathrm{m}^{-3}\right)$ & & $12^{\mathrm{c}}$ & $25.4 \pm 8.0$ & $22.2 \pm 5.0$ & $6^{\mathrm{c}}$ & $12.7 \pm 2.2$ & $25.0 \pm 0.8$ & $27.1 \pm 1.3$ & $28.2 \pm 5.2$ \\
\hline Volatile susp. solids surf. $\left(\mathrm{g} \mathrm{m}^{-3}\right)$ & - & 12 & $6.1 \pm 1.6$ & $6.0 \pm 1.5$ & 6 & $3.9 \pm 0.6$ & $6.4 \pm 0.8$ & $7.5 \pm 0.7$ & $6.4 \pm 0.4$ \\
\hline Volatile susp. solids bot. $\left(\mathrm{g} \mathrm{m}^{-3}\right)$ & - & $12^{\mathrm{c}}$ & $6.5 \pm 1.4$ & $5.8 \pm 1.1$ & $6^{\mathrm{c}}$ & $4.1 \pm 0.4$ & $6.1 \pm 0.4$ & $7.3 \pm 0.5$ & $6.8 \pm 0.6$ \\
\hline Chlorophyll $a$ surf. $\left(\mathrm{mg} \mathrm{m}^{-3}\right)$ & $S c$ & 12 & $3 \pm 0.7$ & $3 \pm 0.8$ & 6 & $3 \pm 0.0$ & $3 \pm 0.8$ & $2 \pm 0.7$ & $2 \pm 0.8$ \\
\hline Chlorophyll $a$ bot. $\left(\mathrm{mg} \mathrm{m}^{-3}\right.$ ) & $B c$ & 12 & $2 \pm 1.1$ & $1 \pm 0.7$ & 6 & $2 \pm 0.5$ & $1 \pm 1.0$ & $2 \pm 0.5$ & $3 \pm 1.6$ \\
\hline
\end{tabular}

${ }^{\mathrm{a}} n=4$ in November.

${ }^{\mathrm{b}} n=10$ in North, $n=4$ in September.

${ }^{\mathrm{c}} n=11$ in South, $n=5$ in May.

revealing some correlations established between the spatial and temporal structure of communities and environmental factors that might be responsible for that structure (e.g. ter Braak, 1995; Cabral, 2000). The CA was performed on a density data matrix that included all species with $>5$ individuals captured (20 species, representing $99.2 \%$ of total catch) in order to reduce the influence of rare or occasional species. The influence of unusually large catches of some fish species in the CA results was reduced by square-root transformation of data. The set of environmental variables used in the covariable matrix was obtained using the following criteria: (a) all initial and final measurements were averaged, (b) surface and bottom measurements were averaged if correlation coefficient $(r)$ presented values $>0.8$, and (c) variables that presented high correlation $(r>0.9)$ with other variables were discarded from analysis. Consequently, the variables used were surface and bottom temperature, surface and bottom salinity, surface and bottom dissolved oxygen concentration, surface and bottom chlorophyll $a$ concentration, water transparency, total suspended solids and grain size characteristics of sediment, whereas volatile suspended solids and organic content of sediment were excluded from the environmental matrix because they were highly correlated to total suspended solids and to fine sand percentage, respectively. The CA was performed using Canoco 4.0 software (ter Braak, 1988).

\section{Results}

\subsection{Environmental characteristics of the sampling area}

Significant temporal and spatial differences were registered in the mean values of the environmental parameters (Tables 1 and 2). Both sampling areas were located on sandy subtidal bottoms. The northern area registered higher depths and higher proportions of fine sand, mud, gravel and organic matter when compared to the southern area where sediment was mainly composed of medium and fine sand. Temperature varied between $14.54 \pm 0.12{ }^{\circ} \mathrm{C}$ (May-North) and $17.94 \pm$ $0.03{ }^{\circ} \mathrm{C}$ (November-South) at bottom, and $15.13 \pm 0.14{ }^{\circ} \mathrm{C}$ (February-South) and $18.55 \pm 0.06{ }^{\circ} \mathrm{C}$ (September-South) at surface. All temporal comparisons were highly significant (a posteriori tests: $P<0.001)$. Salinity varied between $35.11 \pm$ 0.04 (September-North) and 36.26 \pm 0.01 (February-North) at bottom, and between $33.58 \pm 0.97$ (May-North) and 36.14 \pm 0.19 (February-North) at surface. Bottom salinity differed significantly between all sampling dates but surface salinity values only differed in February (a posteriori tests: $P<$ 0.001). Significant differences in bottom temperature and salinity also occurred between areas but were always below $1.00{ }^{\circ} \mathrm{C}$ and 1.00 , respectively, and no consistent pattern was found towards higher bottom temperatures and/or salinities 
Table 2

ANOVA results on spatial and temporal variation in environmental parameters and fish assemblage. "bot." refers to bottom and "surf." to surface measurements

\begin{tabular}{|c|c|c|c|c|c|c|c|c|c|c|c|}
\hline \multirow[t]{2}{*}{ Variable } & \multicolumn{3}{|c|}{ Area } & \multicolumn{3}{|c|}{ Date } & \multicolumn{3}{|c|}{ Area $\times$ date } & \multicolumn{2}{|c|}{ Error } \\
\hline & df & MS & $P$ & df & MS & $P$ & $\mathrm{df}$ & MS & $P$ & df & MS \\
\hline \multicolumn{12}{|l|}{ Sediment } \\
\hline$\% \operatorname{mud}^{\mathrm{a}}$ & 1 & 0.0566 & $* * *$ & 3 & 0.0034 & ns & 3 & 0.0015 & ns & 14 & 0.0019 \\
\hline$\%$ fine sand ${ }^{a}$ & 1 & 1.4144 & $* * *$ & 3 & 0.0385 & ns & 3 & 0.0071 & ns & 14 & 0.0421 \\
\hline$\%$ medium sand $^{\mathrm{a}}$ & 1 & 0.9541 & $* * *$ & 3 & 0.037 & ns & 3 & 0.0114 & ns & 14 & 0.0397 \\
\hline$\%$ coarse sand ${ }^{\mathrm{a}}$ & 1 & 0.0001 & ns & 3 & 0.0028 & ns & 3 & 0.0015 & ns & 14 & 0.0018 \\
\hline$\%$ gravel $^{\mathrm{a}}$ & 1 & 0.0095 & $* * *$ & 3 & 0.0023 & ns & 3 & 0.0007 & ns & 14 & 0.0007 \\
\hline Organic content ${ }^{\mathrm{a}}$ & 1 & 0.0089 & $* * *$ & 3 & 0.0001 & ns & 3 & 0.0000 & ns & 14 & 0.0001 \\
\hline \multicolumn{12}{|l|}{ Water column } \\
\hline Depth & 1 & 594.15 & $* * *$ & 3 & 0.75 & ns & 3 & 0.79 & ns & 40 & 3.71 \\
\hline Temperature surf. & 1 & 0.07 & ns & 3 & 20.59 & $* * *$ & 3 & 0.51 & $* * *$ & 40 & 0.05 \\
\hline Temperature bot. & 1 & 1.87 & $* * *$ & 3 & 20.83 & $* * *$ & 3 & 0.66 & $* * *$ & 40 & 0.02 \\
\hline Salinity surf. & 1 & 0.09 & ns & 3 & 9.42 & $* * *$ & 3 & 1.86 & $* * *$ & 40 & 0.21 \\
\hline Water transparency & 1 & 36053 & $*$ & 3 & 32560 & $* *$ & 3 & 3471 & ns & 14 & 5539 \\
\hline Oxygen surf. & 1 & 0.08 & $*$ & 2 & 7.61 & $* * *$ & 2 & 0.15 & $* *$ & 30 & 0.02 \\
\hline Oxygen bot. & 1 & 2.26 & $* * *$ & 2 & 4.66 & $* * *$ & 2 & 0.58 & $* * *$ & 30 & 0.03 \\
\hline Total susp. solids surf. & 1 & 0.27 & ns & 3 & 288.59 & $* * *$ & 3 & 9.00 & ns & 16 & 3.29 \\
\hline Total susp. solids bot. ${ }^{\mathrm{b}}$ & 1 & 0.001 & ns & 3 & 0.148 & $* * *$ & 3 & 0.017 & $* * *$ & 15 & 0.001 \\
\hline Volatile susp. solids surf. & 1 & 0.18 & ns & 3 & 13.92 & $* * *$ & 3 & 1.46 & $* *$ & 16 & 0.25 \\
\hline Volatile susp. solids bot. & 1 & 1.49 & $* *$ & 3 & 10.40 & $* * *$ & 3 & 0.39 & $*$ & 15 & 0.10 \\
\hline Chlorophyll $a$ surf. $^{\mathrm{c}}$ & 1 & 0.0001 & ns & 3 & 0.09 & ns & 3 & 0.135 & $*$ & 16 & 0.03 \\
\hline Chlorophyll $a$ bot. $^{\mathrm{c}}$ & 1 & 1.301 & $* * *$ & 3 & 0.401 & $* *$ & 3 & 0.166 & $*$ & 16 & 0.048 \\
\hline \multicolumn{12}{|l|}{ Fish assemblage } \\
\hline Species richness ${ }^{\mathrm{c}}$ & 1 & 2 & $* *$ & 3 & 1.98 & $* * *$ & 3 & 0.48 & ns & 16 & 0.22 \\
\hline Abundance $^{c}$ & 1 & 638 & $* *$ & 3 & 227 & ns & 3 & 121 & ns & 16 & 74 \\
\hline Biomass $^{c}$ & 1 & 8248 & ns & 3 & 19685 & $* *$ & 3 & 11915 & $*$ & 16 & 3334 \\
\hline
\end{tabular}

Transformations according to Zar (1999). Level of significance: $* * * P<0.001,{ }^{*} * P<0.01, * P<0.05$, ns, $P>0.05$. ${ }^{\mathrm{a}}$ Arcsin transformation. ${ }^{\mathrm{b}}$ Logarithm transformation. ${ }^{\mathrm{c}}$ Square-root transformation.

in any of the areas. Considering the water column, salinity was always higher at bottom denoting brackish water influence in the upper layers whereas surface-to-bottom differences in temperature indicate that thermal stratification occurred in May (mean difference $=2.14 \pm 0.41{ }^{\circ} \mathrm{C}$ ) and September (mean difference $=1.78 \pm 0.39{ }^{\circ} \mathrm{C}$ ) but not in November (mean difference $=0.03 \pm 0.18{ }^{\circ} \mathrm{C}$ ) and February (mean difference $=-0.10 \pm 0.18^{\circ} \mathrm{C}$ ) when the water column was disturbed by strong SW winds. Water transparency was significantly higher in February when compared to September and November (a posteriori tests: $P<0.05$ ). Oxygen concentrations were consistently above $7 \mathrm{~g} \mathrm{~m}^{-3}$, and significant differences occurred between sampling dates and between areas with a general trend towards lower bottom oxygen levels in November and in the northern area. Suspended and volatile solids concentrations also presented some spatial and temporal variations being significantly lower in May samples (a posteriori tests: $P<0.001)$. Chlorophyll $a$ concentration in the area was low $\left(<4.0 \mathrm{mg} \mathrm{m}^{-3}\right)$. Highly significant spatial differences were nevertheless found in bottom concentrations of northern and southern areas, and between September and February samples (a posteriori tests: $P<$ 0.001).

\subsection{Fish assemblage structure}

A total of 3819 fishes of 18 families and 36 species were collected. The most abundant species were Callionymus lyra, Trachurus trachurus, Arnoglossus laterna, Diplodus bellotti and Echiichthys vipera (Table 3). In terms of mean density the referred group of species also recorded the highest values of mean abundance, but A. laterna assumed higher overall average density than $T$. trachurus (in spite of the lower number of individuals captured) due to its much higher frequency of occurrence. A large fraction of the biomass of the assemblage was also concentrated in a small group of species, namely Raja undulata, C. lyra, Diplodus vulgaris and $D$. bellottii which jointly represented $76 \%$ of total biomass caught. A. laterna, Dicologlossa cuneata, Trigla lucerna and $E$. vipera were the most frequent species in the area being present in more than half of the samples. Juvenile life stages comprehended $50.8 \%$ of total fish caught (mean $=48$ $\pm 20 \%$ of sample catch). Most of the species collected were typically marine species ( $82.1 \%$ of total catch) with only nine known to make significant use of the adjacent estuarine area. In what concerns feeding preferences, invertebrates and bottom-associated fish feeders dominated the assemblage 
Table 3

The fish assemblage of the coastal area adjacent to Tagus estuary. Ecologic and feeding guild classification, number of individual captured ( $N$ ), frequency of occurrence $(F O)$, mean density $(D)$, mean biomass $(B)$, and percentage juvenile stages (\% Juv) are shown along with temporal and spatial variations in density expressed as mean density by sampling date and area, respectively. "CA code" refers to the codes used in correspondence analysis diagram and "?" to lack of length at first maturity data for the species

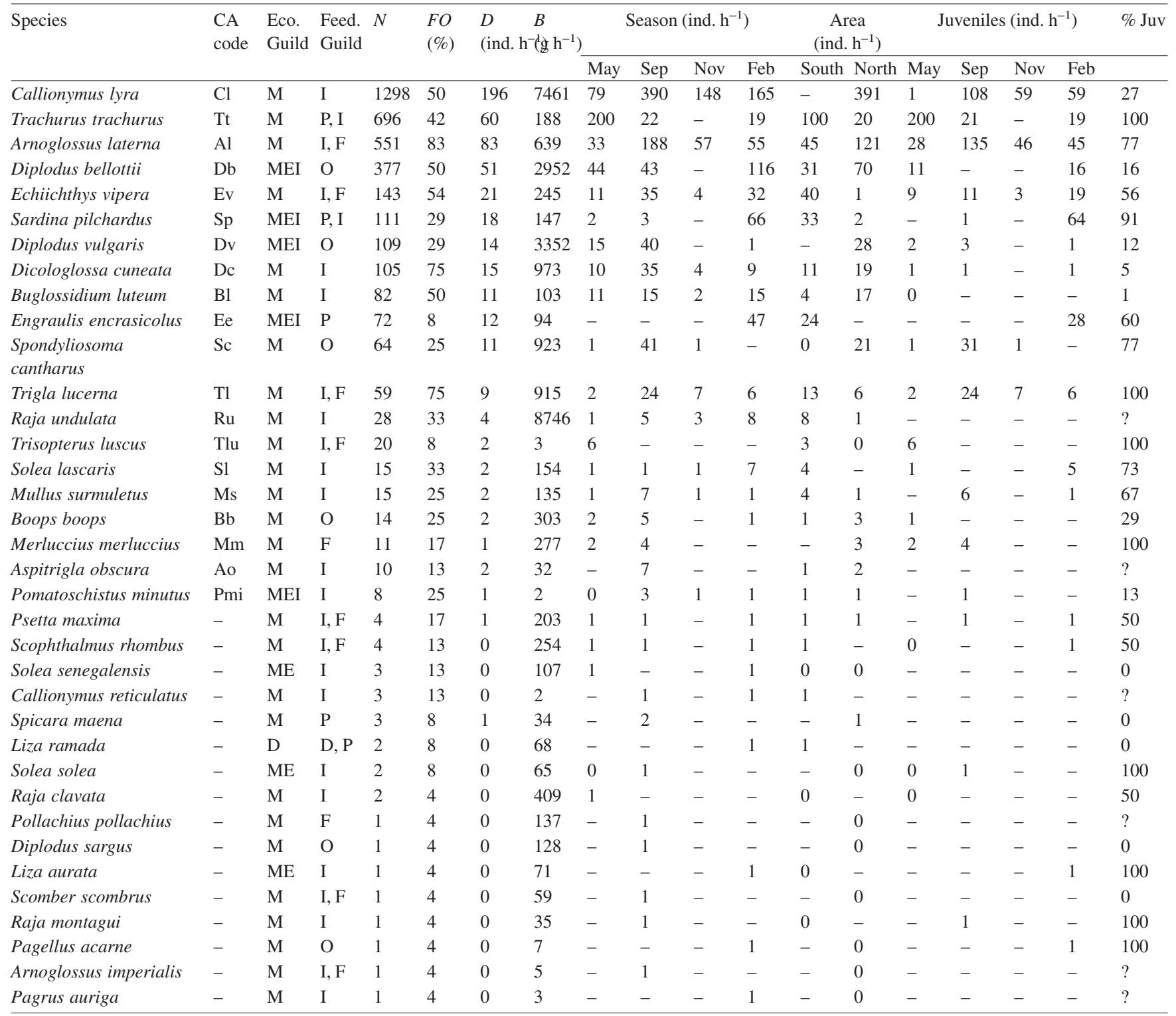

comprising about $90 \%$ of the species sampled. However, the few omnivorous and strictly planktivorous species were important in terms of abundance.

\subsection{Temporal and spatial trends}

The Anova results on fish parameters provide some insight on temporal and spatial variability (Table 2). The two compared areas registered significant differences in fish density and species richness, with a trend towards the occurrence of a higher number of species and higher densities in the samples collected in the northern area (Table 4). Species richness also significantly differed between sampling dates with November samples registering a lower species number than the rest of the samples. A similar temporal trend was observed in biomass (a posteriori test: $P<0.05$ ) (Table 4 ).

In what concerns variations in individual species density, C. lyra and D. vulgaris individuals were only sampled in the northern area while E. vipera, Sardina pilchardus and Engraulis encrasicolus were mostly sampled in the southern area (Table 3). C. lyra and A. laterna were recorded in moderate to high densities in practically all sampling dates but five other abundant species presented density peaks, namely T. trachurus in May, Spondyliosoma cantharus in September, D. bellotti, S. pilchardus and E. encrasicolus in February (Table 3). High densities of juveniles were recorded for A. laterna and C. lyra and also for commercially important species such as T. trachurus, E. encrasicolus, S. pilchar- 
Table 4

Number of species, density (total, adult and juvenile) and biomass per area and sampling date. Mean values and standard deviations are presented. Number in parentheses refers to species richness. $n$ (area) $=12$ and $n$ (date) $=6$

\begin{tabular}{|c|c|c|c|c|c|}
\hline & \multirow[t]{2}{*}{ Number of species } & \multicolumn{3}{|c|}{ Density (ind. $\mathrm{h}^{-1}$ ) } & \multirow[t]{2}{*}{ Biomass $\left(\mathrm{g} \mathrm{h}^{-1}\right)$} \\
\hline & & Total & Adults & Juveniles & \\
\hline \multicolumn{6}{|l|}{ Area } \\
\hline South & $7.0 \pm 3.6(25)$ & $329 \pm 416$ & $91 \pm 122$ & $228 \pm 365$ & $24168 \pm 26083$ \\
\hline North & $10.3 \pm 4.3(28)$ & $712 \pm 496$ & $437 \pm 300$ & $270 \pm 206$ & $34295 \pm 29820$ \\
\hline \multicolumn{6}{|c|}{ Sampling date } \\
\hline May & $9.3 \pm 3.6(23)$ & $423 \pm 457$ & $156 \pm 154$ & $266 \pm 489$ & $16759 \pm 9689$ \\
\hline September & $11.5 \pm 5.1(28)$ & $875 \pm 670$ & $511 \pm 430$ & $350 \pm 253$ & $55469 \pm 33648$ \\
\hline November & $4.2 \pm 1.5(11)$ & $227 \pm 300$ & $109 \pm 158$ & $115 \pm 144$ & $10498 \pm 11216$ \\
\hline February & $9.7 \pm 2.3(24)$ & $556 \pm 287$ & $280 \pm 158$ & $266 \pm 173$ & $34200 \pm 27582$ \\
\hline
\end{tabular}

dus, S. cantharus and T. lucerna. It is noticeable that $D$. bellotti did not present high abundances of juvenile stages regardless of the high abundance of the adult stages in Tagus coastal area.

The first three ordination axes of CA explained $67.1 \%$ of density data, with the first two axes representing by themselves about $50.2 \%$. The first ordination axis separated the northern samples from the southern samples (Fig. 2). In the diagram species like C. lyra, S. cantharus, D. vulgaris and Merluccius merluccius show a preferential distribution near most of the northern area samples, while $R$. undulata, E. vipera, S. pilchardus, E. encrasicolus and Solea lascaris

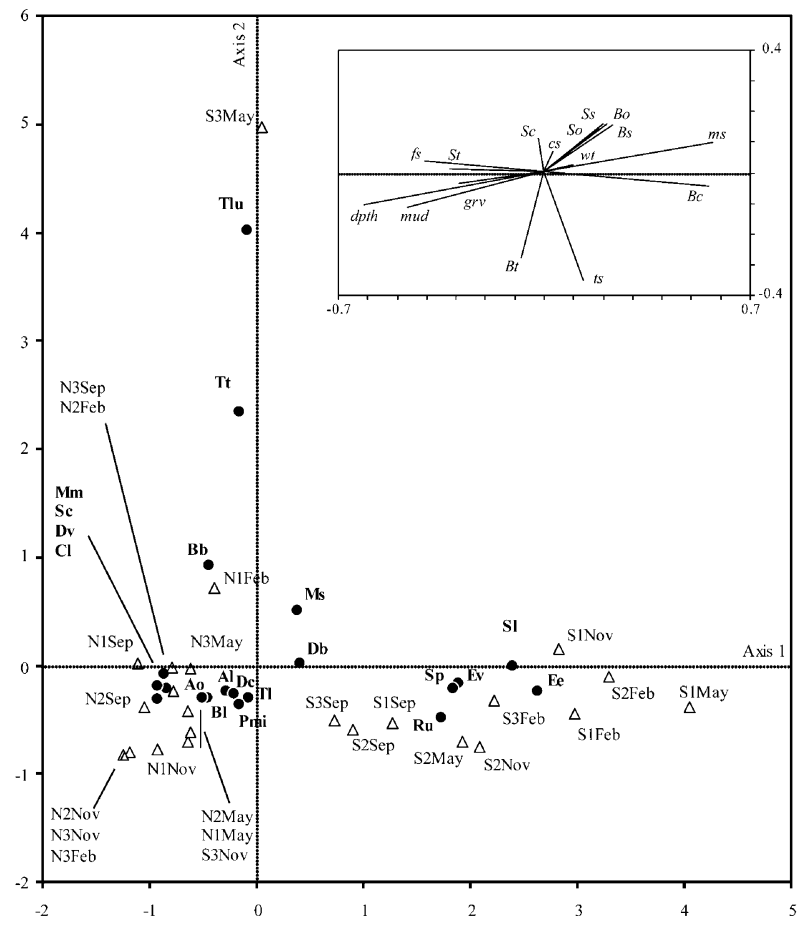

Fig. 2. CA ordination diagram relative to density data (20 species, $99.2 \%$ of total catch). The first two ordination axes represent $50.2 \%$ of total species variance. The eigenvalues of axes 1 and 2 are 0.49 and 0.36 , respectively. The species-environment correlation of axes 1 and 2 are 0.97 and 0.95, respectively. Black dots refer to species (see Table 3 for species codes), open triangles to samples (sample-month). Inset graph presents biplot scores of environmental variables on the two ordination axes (see Table 1 for environmental parameters codes). occur nearer to southern samples. On the contrary, other abundant species like A. laterna, D. bellotti or D. cuneata bear little association to any of these two groups being located near the origin of the diagram. T. trachurus, Trisopterus luscus and sample S3-May are located along the second ordination axis in a distant diagram position because this sample accounted for over $90 \%$ of these species captures. Another atypical position is obtained by sample S3November (that registered four species in low densities, one of them-S. cantharus-that showed strong preference to the northern area in the rest of the samples) and by the sample N1-February (that registered relatively high numbers of $T$. trachurus and D. bellotti when compared to other northern samples). It is also noticeable that the southern group of samples presents a higher dispersion in ordination scores along the first axis than the northern group. This is due to higher variability in species caught in the southern area, where only a few species-E. vipera, S. lascaris and $R$. undulata-showed a consistent presence throughout the year. As to indirect gradient analysis results, $72.8 \%$ of the density matrix species-environment relation was explained in the first three CA axes, with the first two accounting for $54.9 \%$ of the variability. Despite the statistically significant differences between areas and sampling dates (Table 2), high correlations $(>|0.70|)$ of environmental variables with ordination scores only occurred in the first axis, and were mainly related to geographical variables like depth and sediment grain size composition or to chlorophyll $a$ concentration. Correlations of environmental variables with the second axis were all $<|0.50|$.

\section{Discussion}

\subsection{Global patterns}

Although the fishing gear used may have caused some underestimation of flatfish density and biomass estimates (Kuipers et al., 1992), it is not expected to have had a significant effect on the overall structure of the community. In fact, the otter trawl is considered a useful gear for community approaches to demersal fish assemblages providing good quantitative data on both demersal and benthic fish species 
Table 5

Main species (in decreasing order of importance) of the soft-bottom fish assemblage of Tagus coastal area. Note that Cabral et al. (2000) data are based on beach seine catches

\begin{tabular}{|c|c|c|c|}
\hline \multirow{2}{*}{ Rank } & \multirow{2}{*}{$\begin{array}{l}\text { Cabral et al. (2000) } \\
\text { Southern intertidal }\end{array}$} & \multicolumn{2}{|c|}{ This study } \\
\hline & & Southern subtidal & Northern subtidal \\
\hline 1 & Trachurus trachurus & Trachurus trachurus & Callionymus lyra \\
\hline 2 & Scomber japonicus & Arnoglossus laterna & Arnoglossus laterna \\
\hline 3 & Sardina pilchardus & Echiichthys vipera & Diplodus bellottii \\
\hline 4 & Atherina presbyter & Engraulis encrasicolus & Diplodus vulgaris \\
\hline 5 & Trisopterus luscus & Sardina pilchardus & Spondyliosoma cantharus \\
\hline 6 & Buglossidium luteum & Diplodus bellottii & Trachurus trachurus \\
\hline 7 & Diplodus bellotti & Trigla lucerna & Dicologlossa cuneata \\
\hline 8 & Echiichthys vipera & Buglossidium luteum & Buglossidium luteum \\
\hline 9 & Boops boops & Dicologlossa cuneata & Trigla lucerna \\
\hline 10 & Arnoglossus laterna & Trisopterus luscus & Boops boops \\
\hline
\end{tabular}

(Hemingway and Elliott, 2002). However, fast species like the mackerels (He, 1993) and species with a wider distribution in the water column and/or the intertidal areas like Atherina presbyter, that were amongst the dominant species of Cabral et al. (2000) work (Table 5), were practically absent from this study. The absence of these two species from trawl catches may be due to gear selectivity or, more likely, may be related to a more pelagic and/or intertidal distribution. In fact, the beach seine technique used by Cabral et al. (2000) tends to sample most of the water column in mostly intertidal grounds while the otter trawl operates near the bottom in subtidal areas relatively distant from the coast. It should also be noticed that the densities of the smaller individuals of some species are likely to have been underestimated due to trawl mesh selectivity. An analysis of the length-frequency of captures of the 10 most captured species indicated that should be the case of Callionymus lyra and Buglossidium luteum (unpublished data) but is not expected to have occurred in the remaining species (e.g. Diplodus juveniles have been captured in large quantities with the same gear and mesh size inside Tagus estuary).

The subtidal fish assemblage of Tagus coastal area is dominated by a reduced number of species some of which present high fluctuations in densities and biomass throughout the year. A similar structure has been reported in several shallow inshore coastal areas from different parts of the world (e.g. Ross et al., 1987; Wright, 1988; Safran, 1990; Clark et al., 1994; Letourneur et al., 2001). The dominant species in Tagus coastal zone are C. lyra, Arnoglossus laterna, Echiichthys vipera and Diplodus bellottii, although in some periods of the year, Trachurus trachurus, Sardina pilchardus and Engraulis encrasicolus present relatively high densities. In terms of biomass, Raja undulata and $C$. lyra assume the dominance despite the first species low number of individuals captured. As to juvenile composition, the fish assemblage of Tagus coastal waters is very different from the one that uses the nearby Tagus estuary. Our results indicate that significant densities of less commercially important species juveniles like $C$. lyra and A. laterna are present in the area throughout most of the year which may indicate that these two species spawn in the area or in nearby coastal grounds. The presence in some sampling dates of relatively high abundances of juveniles of commercially important species namely T. trachurus, S. pilchardus, Spondyliosoma cantharus, E. encrasicolus, Trisopterus luscus and Trigla lucerna further indicates that this area may be an important nursery ground for these species. As Dicentrachus labrax, Solea solea and Solea senegalensis are the main species that use Tagus estuary as nursery ground (Costa and Cabral, 1999), a significantly different nursery role is carried out by the two adjacent systems. The use of the coastal area by a distinct marine juvenile assemblage is probably related to the fact that it is a relatively shallow water habitat, receiving considerable productivity inputs from the adjacent estuary and where more stable environmental conditions induce lower degrees of environmental stress on marine fish juveniles comparatively to the adjacent estuarine habitat. This idea is strengthened by the fact that most of the species in the area do not make significant use of the adjacent estuary. One such case is T. trachurus whose juveniles are known to form nearshore aggregations (Borges, 1984). Furthermore, the presence of $S$. pilchardus in the area could be related to the fact that estuarine plumes tend to concentrate zooplankton and larval fish forms (Kingsford and Suthers, 1994), a phenomenon that may be enhanced by ebb tide surface eddy formation in the southern sandbanks (Fortunato et al., 1997). Other evidence comes from the increase in species richness in spring to late summer samples. This increase is probably associated to offshore-onshore movements of marine species towards shallower and more productive coastal systems, a similar situation to the reported by Fonds (1983) in the Wadden Sea.

Most of the demersal species of Tagus coastal area feed on infauna and epifauna, or bottom-associated fish. A similar situation has been reported in Tagus estuary and in other estuarine systems (Elliott et al., 2002) and in the French Mediterranean (Letourneur et al., 2001) where the demersal fish assemblage feeds primarily on benthic macrofauna. However, it is noticeable that, contrary to what happens inside Tagus estuary, the Mugilidae family assumes reduced importance in the coastal area, both in the subtidal and intertidal (Cabral et al., 2000). This indicates an important 
trophic difference between the two adjacent locations since mullets assume the detritivorous/benthic microalgae trophic link of Tagus estuarine fish assemblage (Almeida et al., 1993). Furthermore, despite the reduced importance in terms of number of species, planktivorous species such as S. pilchardus, E. encrasicolus and juvenile stages of T. trachurus were abundant in February and May. Since $S$. pilchardus is a pelagic species, planktivory might in fact have assumed high seasonal importance in the system if the whole water column was being considered, a fact that occurs in the coastal intertidal areas (Cabral et al., 2000) and that is less pronounced in the upper areas of Tagus estuary (Moreira et al., 1992).

\subsection{Spatio-temporal patterns: relationships to environmental conditions}

The results of the present study allow, when analysed in conjunction with Cabral et al. (2000) beach seine data, a comprehensive view of both subtidal and intertidal fish assemblages of Tagus coastal area (Table 5). The overall results indicate that at least 64 fish species occur in the area, a number that would most probably increase if the pelagic subtidal area and the northern rocky shore were sampled. Furthermore, the results of the present study show that important changes in fish assemblage structure occur between sites located only a few kilometres apart. Related to this is the fact that the CA plot separated the northern and southern samples revealing the spatial component as the main environmental gradient in species densities, even if high temporal fluctuations in some fish species abundance occur. Furthermore, the CA results indicate that a substantial part of the variability of the fish assemblage may be explained by the studied environmental variables. The most important environmental conditions would then be depth, sediment characteristics and chlorophyll $a$ concentration. However, other environmental variables, biological interactions or a combination of both should also be taken into account when indirectly analysing CA results on fish assemblages and species preferences. In fact, despite the high correlation of depth with the first axis of the CA diagrams (Fig. 2), this variable may only work geographically (since the differences in depth between northern and southern areas-about $10 \mathrm{~m}$ - do not appear to be biologically significant) or, on the contrary, be expressing the influence of some underlying correlated variables. One such variable may be the degree of proximity to the northern rocky shores. The proximity to rocky shores not only increases habitat heterogeneity creating a wider and distinct potential diversity of niches available for fish species but can also modify the macrofauna distribution and abundance in adjacent sandy-bottoms where reef-associated fish species are often seen to forage (Henriques et al., 1999; Barros et al., 2001) leading to significantly different fish assemblages. A possible evidence of the importance of this variable can be found in the highly significant increase in mean species number in samples collected in the northern area and in the strong association to this area of Diplodus vulgaris and S. cantharus, that are frequently caught on areas of convergence of sand, gravel and rocky substrates (Gonçalves and Erzini, 1998). However, quite a different sampling design would be needed to test alternative hypotheses like for example that the degree of exposure to wind, swell or to estuarine outflow might also be determinant. The presence of a small percentage of shell debris in the bottom samples of the northern area (up to $2.5 \%$ ) may be related to the death of reef-associated molluscs redistributed by local currents and wave action (Barros et al., 2001) and may be seen as evidence of reef influence on adjacent soft-bottom areas. Accordingly, the proximity to the rocky environment of the northern coastline should play a more important role in the species distribution than depth. A similar situation may have occurred with the correlation observed between the bottom chlorophyll $a$ concentration and the first axis of the CA plot (Fig. 2). Once more, although statistically significant, the reduced range of variation of chlorophyll $a$ concentration (ca. $4 \mathrm{mg} \mathrm{m}^{-3}$ ) should not present a direct biological significance to the spatial structure of the fish assemblage. Conversely, the CA first axis presents high correlation with type of sand namely with the high percentage of soft sand in northern samples and the high percentage of medium grain sand in southern samples. In contrast to depth and chlorophyll $a$ concentration, sediment composition may in fact be structural in the fish assemblage since, as suggested by the CA analysis, E. vipera abundance has been found to be positively correlated to medium grain size sandy bottoms in the North Sea (Creutzberg and Witte, 1989). Accordingly, $A$. laterna and B. luteum that take a not so high association to the first axis may be expressing the independence of their distribution in relation to sediment type (Amezcua and Nash, 2001). In what concerns C. lyra, its distribution is not known to be dependent on bottom grain size (van der Veer et al., 1990), being found both in muddy and sandy substrates (King et al., 1994). Accordingly, more probable causes to the preferential distribution of this species in the northern area are differences in substrate food availability between the two areas (unpublished data), the opportunistic feeding on rocky shore mussel beds epifauna (López-Jamar et al., 1984; Fernández et al., 1995) or the preference for more sheltered areas since the northern area of the Tagus mouth registers lower tidal currents speeds (Fortunato et al., 1997) and is also less exposed to the dominant winds due to northward presence of mountainous formations. As to D. bellotti, it is a species with southern affinities that has been extending northwards its distribution range (Cabral et al., 2001). In the Tagus coastal area, it is commonly found both in the northern and southern areas, showing no abundance trend within the range of the measured environmental variables (Fig. 2).

It is also noticeable that $\mathrm{CA}$ axes presented reduced correlations with environmental parameters even if they registered considerable fluctuations throughout the year. Regarding that salinity and temperature frequently appointed as important factors influencing species distribution in coastal and estuarine ecosystems (Fonds, 1983; Thiel et al., 1995), the absence of a recognizable temporal pattern in the dia- 
grams may be related either to sampling strategy limitations or to the particular winter climatic situation that took place during the sampling events. Dry periods are known to occur frequently in the Iberian Peninsula and in 2001/2002 reflected themselves in smaller salinity and temperature variations than it would be expected based on the typically seasonal outflow regime of Tagus estuary and on the proximity of the sampling areas to the estuary mouth. Evidence of the possible effect of a year's specific climatic regime in community structure was obtained during preliminary sampling activities carried out in the 2000/2001 winter when salinities and water temperatures in the southern area were frequently below 30 and $15{ }^{\circ} \mathrm{C}$, respectively, and appreciable densities of juvenile Argyrosomus regius were recorded. It is significant that in the following winter, A. regius juveniles were not captured since the use of the coastal areas near estuaries as overwintering areas by this species has been related to winter reduction in estuarine temperatures (Quéro and Vayne, 1987) and $A$. regius juveniles were very abundant throughout 2002 inside Tagus estuary (unpublished data). Regarding these facts, the importance of typically seasonal environmental variables like temperature and salinity to fish assemblage structure in this area should be interpreted with caution until a more comprehensive annual and seasonal sampling scheme can be accomplished.

\section{Conclusion}

The subtidal fish assemblage of Tagus estuary coastal area is dominated by a reduced number of typically marine species. However, significant immigration movements occur from offshore into this coastal area, especially during spring and summer. The number and species of juvenile life stages present in the area indicates that it may be used by some marine species as a nursery area. When compared to Tagus estuary, this nursery function is used by a different array of marine species. Most of the variability in the fish assemblage can be explained by typical geographical variables like depth and sediment characteristics although these may be correlated to the proximity to northern rocky shores or the degree of exposure to winds and swell. Consequently, the possible existence along estuarine-coastal gradients of structurally and functionally distinct fish assemblages should be taken into account when developing management strategies for coastal ecosystems.

\section{Acknowledgements}

The authors would like to thank everyone involved in sampling surveys, Sofia Santiago for chemical analysis, and the reviewers for their helpful comments and suggestions. This study was supported by Fundação para a Ciência e a Tecnologia (FCT) as part of project PDCTM/C/MAR/ $15263 / 1999$. Additional support came from project fellowships to N. Prista and R.P. Vasconcelos.

\section{Appendix A}

Size at first maturity considered in juvenile stage quantification. "Fishbase calculation" refers to the usage of site www.fishbase.org for determination of length at first maturity based on growth parameters for the species; "average of sexes" refers to average of female and male lengths; "combined" refers to overall size at first maturity determined by authors based on both sexes

\begin{tabular}{|c|c|c|c|}
\hline Species & $\begin{array}{l}\text { Length } \\
(\mathrm{mm})\end{array}$ & Source & Type of data \\
\hline Arnoglossus imperialis & - & - & - \\
\hline Arnoglossus laterna & 109 & Deniel (1984) & Females \\
\hline Aspitrigla obscura & - & - & - \\
\hline Boops boops & 143 & Gordo (1992) & Average of sexes \\
\hline Buglossidium luteum & 80 & Deniel (1984) & Females \\
\hline Callionymus lyra & 122 & King et al. (1994) & Average of sexes \\
\hline Callionymus reticulatus & - & - & - \\
\hline Diplodus bellottii & 117 & $\begin{array}{l}\text { Santos et al. } \\
\text { (1998) }\end{array}$ & Average of sexes \\
\hline Dicologlossa cuneata & 170 & Dinis (1986) & Females \\
\hline Diplodus sargus & 173 & $\begin{array}{l}\text { Erzini et al. } \\
(2001)\end{array}$ & Combined \\
\hline Diplodus vulgaris & 172 & $\begin{array}{l}\text { Erzini et al. } \\
(2001)\end{array}$ & Combined \\
\hline Engraulis encrasicolus & 111 & Millan (1999) & Average \\
\hline Echiichthys vipera & 95 & $\begin{array}{l}\text { Creutzberg and } \\
\text { Witte (1989) }\end{array}$ & $\begin{array}{l}\text { Fishbase } \\
\text { calculation }\end{array}$ \\
\hline Liza aurata & 300 & Almeida (1996) & Females \\
\hline Liza ramada & 240 & Almeida (1996) & Females \\
\hline Merluccius merluccius & 422 & $\begin{array}{l}\text { Lucio et al. } \\
\text { (1998) }\end{array}$ & Combined \\
\hline Mullus surmuletus & 175 & Quéro (1984) & Average of sexes \\
\hline Pagellus acarne & 177 & $\begin{array}{l}\text { Erzini et al. } \\
\text { (2001) }\end{array}$ & Combined \\
\hline Pagrus auriga & - & - & - \\
\hline Psetta maxima & 310 & Quéro (1984) & Average of sexes \\
\hline Pomatoschistus minutus & 50 & $\begin{array}{l}\text { Arruda et al. } \\
\text { (1993) }\end{array}$ & Average of sexes \\
\hline Pollachius pollachius & - & - & - \\
\hline Raja clavata & 725 & Quéro (1984) & Average of sexes \\
\hline Raja montagui & 625 & Quéro (1984) & Average of sexes \\
\hline Raja undulata & - & - & - \\
\hline $\begin{array}{l}\text { Spondyliosoma } \\
\text { cantharus }\end{array}$ & 185 & $\begin{array}{l}\text { Erzini et al. } \\
(2001)\end{array}$ & Combined \\
\hline Solea lascaris & 219 & Gomes (2000) & Females \\
\hline Spicara maena & 149 & $\begin{array}{l}\text { Dulčić et al. } \\
(2000)\end{array}$ & $\begin{array}{l}\text { Fishbase } \\
\text { calculation }\end{array}$ \\
\hline Sardina pilchardus & 155 & $\begin{array}{l}\text { Figueiredo and } \\
\text { Santos (1988) }\end{array}$ & Both sexes \\
\hline Scophthalmus rhombus & 310 & Quéro (1984) & Average of sexes \\
\hline Scomber scombrus & 245 & $\begin{array}{l}\text { Regule and } \\
\text { Cuadros (1987) }\end{array}$ & Average of sexes \\
\hline Solea senegalensis & 300 & Dinis (1986) & Females \\
\hline Solea solea & 320 & Dinis (1986) & Females \\
\hline Trigla lucerna & 378 & Baron (1985) & Average of sexes \\
\hline Trisopterus luscus & 190 & Sobral (1985) & Average of sexes \\
\hline Trachurus trachurus & 225 & $\begin{array}{l}\text { Borges and } \\
\text { Gordo (1991) }\end{array}$ & Females \\
\hline
\end{tabular}




\section{References}

Almeida, P.R., 1996. Biologia e ecologia de Liza ramada (Risso, 1826) e Chelon labrosus (Risso, 1826) (Pisces, Mugilidae) no estuário do Mira (Portugal). Inter-relações com o ecossistema estuarino. Universidade de Lisboa, Lisbon Ph.D. thesis (in Portuguese).

Almeida, P.R., Moreira, F., Costa, J.L., Assis, C.A., Costa, M.J., 1993. The feeding strategies of Liza ramada (Risso, 1826) in fresh and brackish water in the River Tagus, Portugal. J. Fish Biol. 42, 95-107.

Amezcua, F., Nash, R.D.M., 2001. Distribution of the order Pleuronectiformes in relation to the sediment type in the North Irish Sea. J. Sea Res. 45, 293-301.

Arruda, L., Azevedo, J.M.N., Neto, I., 1993. Abundance, age-structure and reproduction of gobies (Pisces, Gobiidae) in the Ria de Aveiro Lagoon (Portugal). Estuar. Coast. Shelf Sci. 37, 509-523.

Baron, J., 1985. Les triglides (Teleosteens, Scorpaeniformes) de la Baie de Douarnenez-II. La reproduction de: Eutrigla gurnardus, Trigla lucerna, Trigloporus lastoviza et Aspitrigla cuculus. Cybium 9, 255-281.

Barros, F., Underwood, A.J., Lindegarth, M., 2001. The influence of rocky reefs on structure of benthic macrofauna in nearby soft-sediments. Estuar. Coast. Shelf Sci. 52, 191-199.

Blaber, S.J.M., Brewer, D.T., Salini, J.P., 1989. Species composition and biomasses of fishes in different habitats of a tropical Northern Australian estuary: their occurrence in the adjoining sea and estuarine dependence. Estuar. Coast. Shelf Sci. 29, 509-531.

Blaber, S.J.M., Brewer, D.T., Salini, J.P., 1995. Fish communities and the nursery role of the shallow inshore waters of a tropical bay in the Gulf of Carpentaria, Australia. Estuar. Coast. Shelf Sci. 40, 177-193.

Borges, M.F., 1984. Evaluation of the results on horse mackerel (Trachurus trachurus L.) of a series of young fish surveys in the Portuguese waters (Division IX). ICES CM 1984/H:26. International Council for the Exploration of the Sea, Copenhagen.

Borges, M.F., Gordo, L.S., 1991. Spatial distribution by season and some biological parameters of horse mackerel (Trachurus trachurus L.) in the Portuguese continental waters (Division IXa). ICES-CM-1991/H:54. International Council for the Exploration of the Sea, Copenhagen.

Cabeçadas, G., Brogueira, M.J., Cabeçadas, L., 2000. Southern Portugal: the Tagus and Sado estuaries. In: Sheppard, C.R.C. (Ed.), Seas at the Millennium: an Environmental Evaluation. Regional Chapters: Europe, the Americas and West Africa, vol. 1. Elsevier, Amsterdam, pp. 151-165.

Cabral, H.N., 2000. Distribution and abundance patterns of flatfishes in the Sado estuary, Portugal. Estuaries 23, 351-358.

Cabral, H.N., Costa, M.J., Salgado, J.P., 2001. Does the Tagus estuary fish community reflect environmental changes? Clim. Res. 18, 119-126.

Cabral, H.N., Duque, J., Costa, M.J., 2000. Importance of the coastal zone adjacent to the Tagus estuary as a nursery area for fish. Thalassas 16, 27-32.

Clark, B.M., Bennett, B.A., Lamberth, S.J., 1994. A comparison of the ichthyofauna of two estuaries and their adjacent surf zones, with an assessment of the effects of beach-seining on the nursery function of estuaries for fish. South Afr. J. Mar. Sci.-Suid-Afr. Tydsk. Seewetens. 14, 121-131.

Clesceri, L.S., Greenberg, A.E., Eaton, A.D., 1998. Standard Methods for the Examination of Water and Wastewater. American Public Health Association, American Water Works Association, Water Environment Federation (Joint Publishers), Washington, D.C., USA.

Costa, M.J., Bruxelas, A., 1989. The structure of fish communities in the Tagus Estuary, Portugal, and its role as a nursery for commercial fish species. Sci. Mar. 53, 561-566.

Costa, M.J., Cabral, H.N., 1999. Changes in the Tagus nursery function for commercial fish species: some perspectives for management. Aquat. Ecol. 33, 287-292.

Creutzberg, F., Witte, J.I.J., 1989. An attempt to estimate the predatory pressure exerted by the lesser weever, Trachinus vipera Cuvier, in the southern North Sea. J. Fish Biol. 34, 429-449.
Day, J.H., Blaber, S.J.M., Wallace, J.H., 1981. Estuarine fishes. In: Day, J.H. (Ed.), Estuarine Ecology with Particular Reference to Southern Africa. A.A. Balkema, Cape Town, pp. 197-221.

Deniel, C., 1984. Relations entre l'activité reproductrice et la croissance chez les poissons plats de la baie de Douarnenez. Cybium 8, 83-93.

Dias, J.M.A., 1987. Dinâmica sedimentar e evolução recente da plataforma continental portuguesa setentrional. Universidade de Lisboa, Lisbon Ph.D. thesis (in Portuguese).

Dinis, M.T., 1986. Quatre Soleidae de l'estuaire du Tage. Reproduction et croissance. Essai d'elevage de Solea senegalensis Kaup. Université de Bretagne Occidentale, Brest Ph.D. thesis.

Dulčić, J., Kraljević, M., Grbec, B., Cetinić, P., 2000. Age, growth and mortality of blotched picarel Spicara maena L. (Pisces: Centracanthidae) in the eastern central Adriatic. Fish. Res. 48, 69-78.

Elliott, M., Dewailly, F., 1995. The structure and components of European estuarine fish assemblages. Neth. J. Aquat. Ecol. 29, 397-417.

Elliott, M., Hemingway, K.L., Costello, M.J., Duhamel, S., Hostens, K., Labropoulou, M., Marshall, S., Winkler, H., 2002. Links between fish and other trophic levels. In: Elliott, M., Hemingway, K. (Eds.), Fishes in Estuaries. Blackwell Science, Oxford, pp. 124-216.

Erzini, K., Bentes, L., Coelho, R., Correia, C., Lino, P.G., Monteiro, P., Ribeiro, J., Gonçalves, J.M.S., 2001. Fisheries biology and assessment of demersal species (Sparidae) from the South of Portugal. DG XIV/C/1 98/082. Commission of the European Communities. Centro de Ciências do Mar, Universidade do Algarve, Faro.

Fernández, L., Freire, J., González-Gurriarán, E., 1995. Diel feeding activity of demersal fishes in the Ría de Arousa (Galicia, NW Spain): an area of intense mussel raft culture. Cah. Biol. Mar. 36, 141-151.

Figueiredo, I.V., Santos, A.M., 1988. On sexual maturation, condition factor and gonosomatic index of Sardina pilchardus Walb., off Portugal (1986/1987). ICES-CM-1988/H:70. International Council for the Exploration of the Sea, Copenhagen.

Fiúza, A.F.G., Macedo, M.E., Guerreiro, M.R., 1982. Climatological space and time variation of the Portuguese coastal upwelling. Oceanol. Acta 5, 31-40.

Fonds, M., 1983. The seasonal distribution of some fish species in the Western Dutch Wadden Sea. In: Wolff, W.J. (Ed.), Ecology of the Wadden Sea, vol. II. A.A. Balkema, Rotterdam, pp. 5/43-5/77.

Fortunato, A.B., Baptista, A.M., Luettich Jr., R.A., 1997. A threedimensional model of tidal currents in the mouth of the Tagus estuary. Cont. Shelf Res. 17, 1689-1714.

Gaudêncio, M.J., Guerra, M.T., Glémarec, M., 1991. Recherches biosédimentaires sur la zone maritime de l'estuaire du Tage, Portugal: donnés sédimentaires préliminaires. In: Elliott, M., Ducrotoy, J.P. (Eds.), Estuaries and Coasts: Spatial and Temporal Intercomparisons. Olsen \& Olsen, Fredensborg, pp. 11-16.

Gomes, T.M.M.F.G., 2000. Reprodução e fecundidade de Solea lascaris (Risso, 1810) em águas costeiras do Norte de Portugal. Universidade do Porto, Porto M.Sc. thesis (in Portuguese).

Gonçalves, J.M.S., Erzini, K., 1998. Feeding habits of the two-banded sea bream (Diplodus vulgaris) and the black sea bream (Spondyliosoma cantharus) (Sparidae) from the South-West coast of Portugal. Cybium 22, 245-254.

Gordo, L.S., 1992. Contribuição para o conhecimento da biologia e do estado de exploração do stock de boga [Boops boops (L., 1758)] da costa portuguesa. Universidade de Lisboa, Lisbon Ph.D. thesis (in Portuguese).

He, P., 1993. Swimming speeds of marine fish in relation to fishing gears. ICES Mar. Sci. Symposia 196, 183-189.

Heiri, O., Lotter, A.F., Lemcke, G., 2001. Loss on ignition as a method for estimating organic and carbonate content in sediments: reproducibility and comparability of results. J. Paleolimnol. 25, 101-110.

Hemingway, K.L., Elliott, M., 2002. Field methods. In: Elliott, M., Hemingway, K. (Eds.), Fishes in Estuaries. Blackwell Science, Oxford, pp. 410509 . 
Henriques, M., Gonçalves, E.J., Almada, V.C., 1999. The conservation of littoral fish communities: a case study at Arrábida coast (Portugal). In: Almada, V.C., Oliveira, R.F., Gonçalves, E.J. (Eds.), Behaviour and Conservation of Littoral Fishes. ISPA, Lisbon, Portugal, pp. 473-519.

Jouanneau, J.M., Garcia, C., Oliveira, A., Rodrigues, A., Dias, J.A., Weber, O., 1998. Dispersal and deposition of suspended sediment on the shelf off the Tagus and Sado estuaries, S.W. Portugal. Prog. Oceanogr. 42, 233-257.

King, P.A., Fives, J.M., McGrath, D., 1994. Reproduction, growth and feeding of the dragonet, Callionymus lyra (Teleostei: Callionymidae), in Galway Bay, Ireland. J. Mar. Biol. Assoc. UK 74, 513-526.

Kingsford, M.J., Suthers, I.M., 1994. Dynamic estuarine plumes and fronts: importance to small fish and plankton in coastal waters of NSW, Australia. Cont. Shelf Res. 14, 655-672.

Kuipers, B.R., MacCurrin, B., Miller, J.M., van der Veer, H.W., Witte, J.I.J., 1992. Small trawls in juvenile flatfish research: their development and efficiency. Neth. J. Sea Res. 29, 109-117.

Lenanton, R.C.J., 1982. Alternative non-estuarine nursery habitats for some commercially and recreationally important fish species of South-western Australia. Aust. J. Mar. Fresh. Res. 33, 881-900.

Lenanton, R.C.J., Potter, I.C., 1987. Contribution of estuaries to commercial fisheries in temperate Western Australia and the concept of estuarine dependence. Estuaries 10, 28-35.

Letourneur, Y., Darnaude, A., Salen-Picard, C., Harmelin-Vivien, M.L., 2001. Spatial and temporal variations of fish assemblages in a shallow Mediterranean soft-bottom area (Gulf of Fos, France). Oceanol. Acta 24, 273-285.

López-Jamar, E., Iglesias, J., Otero, J.J., 1984. Contribution of infauna and mussel-raft epifauna to demersal fish diets. Mar. Ecol. Progr. Ser. 15, 13-18.

Lorenzen, C.J., 1967. Determination of chlorophyll and phaeo-pigments: spectrophotometric equations. Limnol. Oceanogr. 12, 343-346.

Lucio, P., Santurtun, M., Murua, H., 1998. Growth and reproduction of hake (Merluccius merluccius) in the Bay of Biscay during 1996-1997. ICESCM-1998/CC:20. International Council for the Exploration of the Sea, Copenhagen.

Marshall, S., Elliott, M., 1998. Environmental influences on the fish assemblage of the Humber estuary, UK. Estuar. Coast. Shelf Sci. 46, 175-184.

Millan, M., 1999. Reproductive characteristics and condition status of anchovy Engraulis encrasicolus L. from the Bay of Cadiz (SW Spain). Fish. Res. 41, 73-86.
Moreira, F., Assis, C.A., Almeida, P.R., Costa, J.L., Costa, M.J., 1992. Trophic relationships in the community of the upper Tagus estuary (Portugal): a preliminary approach. Estuar. Coast. Shelf Sci. 34, 617623.

Quéro, J.-C., 1984. Les Poissons de Mer des Pêches Françaises. Jacques Grancher, Paris.

Quéro, J.-C., Vayne, J.-J., 1987. Le maigre, Argyrosomus regius (Asso, 1801) (Pisces, Perciformes, Sciaenidae) du Golfe de Gascogne et des eaux plus septentrionales. Rev. Trav. Inst. Pêches Marit. 49, 35-66.

Regule, J.L.H., Cuadros, M.L.V., 1987. Biometry, growth, reproduction and fishing of mackerel Scomber scombrus, L. 1768, along the Asturian coast (North of Spain) in 1985. ICES-CM-1987/H:5. International Council for the Exploration of the Sea, Copenhagen.

Ross, S.T., McMichael Jr., R.H., Ruple, D.L., 1987. Seasonal and diel variation in the standing crop of fishes and macroinvertebrates from a Gulf of Mexico surf zone. Estuar. Coast. Shelf Sci. 25, 391-412.

Safran, P., 1990. Spatio-temporal variability in the structure of a nectobenthic fish nursery: a descriptive study. Oceanol. Acta 13, 97-106.

Santos, M.N., Monteiro, C.C., Erzini, K., Lasserre, G., 1998. Maturation and gill-net selectivity of two small sea breams (genus Diplodus) from the Algarve coast (South Portugal). Fish. Res. 36, 185-194.

Sobral, M., 1985. Actividade relativa ao estudo da faneca-Trisopterus luscus L.—em 1983. Resultados preliminares sobre o ciclo reprodutivo, idade e crescimento. Relatório Interno ${ }^{\circ} 95$ INIP, Lisbon, Portugal (in Portuguese).

ter Braak, C.J.F., 1988. CANOCO—a Fortran Program for Canonical Community Ordination by Partial Detrended Canonical Correspondence Analysis, Principal Components and Redundancy Analysis. Agricultural and Mathematical Group, Wageningen.

ter Braak, C.J.F., 1995. Ordination. In: Jongman, R.H.G., ter Braak, C.J.F., van Togeren, O.F.R. (Eds.), Data Analysis in Community and Landscape Ecology. Cambridge University Press, Cambridge, pp. 91-173.

Thiel, R., Sepúlveda, A., Kafemann, R., Nellen, W., 1995. Environmental factors as forces structuring the fish community of the Elbe Estuary. J. Fish Biol. 46, 47-69.

van der Veer, H.W., Creutzberg, F., Dapper, R., Duineveld, G.C.A., Fonds, M., Kuipers, B.R., van Noort, G.J., Witte, J.I.J., 1990. On the ecology of the dragonet Callionymus lyra L. in the southern North Sea. Neth. J. Sea Res. 26, 139-150.

Whitfield, A.K., 1999. Icthyofaunal assemblages in estuaries: a South African case study. Rev. Fish. Biol. Fish. 9, 151-186.

Wright, J.M., 1988. Seasonal and spatial differences in the fish assemblage of the non-estuarine Sulaibikhat bay, Kuwait. Mar. Biol. 100, 13-20.

Zar, J.H., 1999. Biostatistical Analysis. Prentice-Hall, New Jersey. 